\title{
Infectious Diseases in Internationally Adopted Children and Intercountry Discrepancies Among Screening Protocols, A Narrative Review
}

\author{
Elena Chiappini ${ }^{*}$ Barbara Bortone, Sara Borgi, Sara Sollai, Tommaso Matucci, Luisa Galli \\ and Maurizio de Martino
}

Department of Health Science, Anna Meyer Children University Hospital, University of Florence, Florence, Italy

Internationally adopted children (IAC) require thorough health assessments at time of arrival in the host country. As these children are at higher risk for infectious diseases, such as gastrointestinal parasites, tuberculosis, hepatitis, syphilis, and human immunodeficiency virus, early diagnosis of infectious diseases is fundamental for the optimal management of the child and, also, to reduce the risk of transmission to

\section{OPEN ACCESS}

Edited by:

Henrique Barros,

University of Porto, Portugal

Reviewed by:

Ruud Gerard Nijman, Imperial College London,

United Kingdom

Frederic Sorge,

Institut Pasteur, France

*Correspondence:

Elena Chiappini

elena.chiappini@unifi.it

Specialty section:

This article was submitted to General Pediatrics and Pediatric

Emergency Care

a section of the journal

Frontiers in Pediatrics

Received: 13 December 2018

Accepted: 15 October 2019

Published: 07 November 2019

Citation:

Chiappini E, Bortone B, Borgi S,

Sollai S, Matucci T, Galli L and

de Martino M (2019) Infectious

Diseases in Internationally Adopted

Children and Intercountry

Discrepancies Among Screening

Protocols, A Narrative Review.

Front. Pediatr. 7:448.

doi: 10.3389/fped.2019.00448 the adopting community. Comparative analysis of the screening protocols adopted in Europe, the United States, and Canada revealed different approaches to the adopted children. A homogeneous and internationally shared standard of care in the management of IAC should be provided.

Keywords: internationally adopted children, infectious diseases, screening, protocols, tuberculosis, parasites

\section{INTRODUCTION}

Infectious diseases are commonly reported in internationally adopted children (IAC) (1), and their need for rapid, cautious, and thorough screenings has been underlined by several authors (1-5). A recent Italian study indicated that clinical conditions affecting IAC, ranging from congenital malformations, to complex infectious diseases, such as tuberculosis infection (observed in 15\% of children included) and parasitosis (in more than 20\%), to non-severe and easily treatable infections, such as Molluscum contagiosum and fungal skin infections, have been frequently reported. Notably, about $40 \%$ of IAC presented at least one infectious disease (2).

Although IAC require medical evaluation and health certifications before adoption, many diseases may remain undiagnosed (3-5).

Early diagnosis of infectious diseases is crucial both for the optimal management of IAC and to reduce risk of transmission to the community $(1,6,7)$. Cases of transmission of the Hepatitis $A$ and Hepatitis B viruses, scabies, tuberculosis, Tinea capitis/corporis, and measles to adoptive families have been reported in the literature $(1,6,7)$.

A narrative review of the literature was conducted to identify and compare the screening protocols used by different countries and to discuss the major discrepancies between them.

\section{METHODS}

Post-adoption screening protocols were identified by searching the guidelines websites and national adoption association websites of countries reported to receive the highest number of IAC (United States, Italy, Spain, Canada, and France) (8). Moreover, PubMed was consulted 
with the search strategy: (international* OR abroad) AND ("adopted children" OR adoption OR adoptees) AND ("infectious diseases" OR infection*). The reference lists of the retrieved articles were analyzed. A comparison among the retrieved protocols was performed, focusing on screening for infectious diseases. Moreover, a narrative review of the literature was performed to discuss discrepancies.

\section{RESULTS}

Six different protocols were identified (9-14), published in the United Kingdom (UK), Spain, Italy, Canada, France, and the United States (US). Four protocols were retrieved by searching national adoption association websites $(10-12,14)$ and two by searching the reference lists of results from PubMed (913). Except for the French protocol, which is provided by the Centre Hospitalier Universitaire de Nantes (13), all the others were national protocols $(9-12,14)$. The English protocol was published in 2004 (9), the Spanish protocol in 2008 (10), and the four others between 2013 and 2017 (11-14). Their recommendations have been summarized in Table 1 .

\section{HISTORY}

All the retrieved protocols include a proper analysis of history to describe the adoption process, the child's life before adoption, any host institutions where the child lived, the child's psychophysical development, and any certified vaccinations. Recent and remote pathological anamnesis, previous laboratory tests, instrumental examinations, and specialist evaluations, whenever available, are necessary. Additionally, clinical histories of the biological family need to be reviewed and added to the report (9-14).

\section{SKIN PROBLEMS}

A global clinical evaluation should be performed with particular attention to skin and genital examination (9-14).

Skin infections in IAC are very common (6); having lived in an overcrowded institution and coming from a tropical country are the main risk factors for this type of infection. The most frequently reported dermatological disease is Tinea capitis infection, followed by Molluscum contagiosum, pediculosis of the head, and impetigo; scabies is frequently observed and should be promptly diagnosed and treated $(6,7)$. Skin examination is also crucial to detect a Bacille Calmette Guerin (BCG) scar and scars compatible with previous infections, such as varicella zoster infection (9-14).

\section{SCREENING TESTS}

\section{Tuberculosis}

While the tuberculin skin test (TST) is the first choice in the UK, Spain, Italy, and France $(9-11,13)$, Interferon- $\gamma$ release assays (IGRA) can be an acceptable screening alternative in Canada and the US in children older than 5 and 2 years, respectively $(12,14)$.

\section{HAV}

Screening for hepatitis A (HAV) is not routinely recommended in IAC in UK and Italy $(9,11)$, but it is suggested in Canada France, and the US (12-14) and in IAC from Latin America arriving in Spain (10).

\section{HBV}

HBV screening is recommended by all of the guidelines reviewed. Italy, Canada, and the US recommend HBsAg and HBsAb (11, $12,14)$, whereas the UK, Spain, and France also include $\mathrm{HBcAb}$ (9, 10, 13). The UK, Italy, Canada, and the US recommend repeating the serology after a window period if the first test is negative $(9,11,12,14)$.

\section{Malaria}

Only the UK protocol recommends routine screening for malaria upon arrival in all IAC coming from an endemic area (9), while all the other protocols suggest it only in IAC coming from endemic areas with fever (13) and/or hepato-splenomegaly $(10-12,14)$.

\section{Other Parasitoses}

An ova and parasite exam on three stool samples is routinely recommended by all of the protocols, except for that in the UK, which recommends the test only to children who have lived in poor sanitary conditions, have been institutionalized, or have an anamnestic history of diarrhea (9). Serologic testing for Strongyloides spp. and Toxocara canis is recommended in children where there is clinical suspicion or with eosinophilia and a negative ova and parasite exam in Italy and the US $(11,14)$; only in Canada is Strongyloides spp. routinely investigated in all IAC coming from Africa and Southeast Asia (12).

Serologic testing for Schistosoma is indicated in Canada and the US in IAC coming from endemic areas $(12,14)$.

Serologic testing for Trypanosoma cruzi is routinely performed only in Spain and in US IAC (10, 14) coming from endemic countries, while in other countries this test is not recommended $(9,11-13)$.

Anti-cysticercus IgG antibodies are not recommended by any protocol, not even among IAC coming from endemic countries (9-14).

\section{Syphilis}

All the retrieved protocols recommend screening for syphilis, but there is no concordance as regards the choice of treponemal or nor-treponemal antibodies. Only non-treponemal serologic testing is recommended in the UK, Spain, and Canada (9, 10, $12)$; both treponemal and non-treponemal tests are routinely indicated in France and in the US $(13,14)$. The Italian protocol does not specify the serologic pattern required (11).

\section{DISCUSSION}

This paper focuses on the screening protocols for infectious diseases in newly arrived IAC. It is important to specify that many other issues must be considered when managing IAC, such as immunization coverage, auxo-endocrinological problems, and other non-infectious diseases. 
TABLE 1 | Laboratory microbiological tests recommended in different screening protocols.

\begin{tabular}{|c|c|c|c|c|c|c|}
\hline Laboratory tests & UK 2004 (9) & Spain 2008 (10) & Italy 2013 (11) & Canada 2014 (12) & France 2015 (13) & US 2017 (14) \\
\hline HBV serologic testing & $\begin{array}{l}\text { To all IAC; repeat } \\
\text { after } 3 \text { months; } \\
\text { HbSAb, } \\
\text { HBSAg, } \\
\text { anti-HBc Ab }\end{array}$ & $\begin{array}{l}\text { To all IAC; } \\
\text { HbSAb, } \\
\text { HBSAg, } \\
\text { anti-HBc Ab }\end{array}$ & $\begin{array}{l}\text { To all IAC; } \\
\text { consider window } \\
\text { period } \\
\text { Antibodies } \\
\text { not specified. }\end{array}$ & $\begin{array}{l}\text { To all IAC; repeat } \\
\text { after } 6 \text { months } \\
\text { HbSAb, } \\
\text { HBSAg }\end{array}$ & $\begin{array}{l}\text { To all IAC } \\
\text { HbSAb, } \\
\text { HBSAg, } \\
\text { anti-HBc Ab }\end{array}$ & $\begin{array}{l}\text { To all IAC; repeat } \\
\text { after } 6 \text { months } \\
\text { HbSAb, HBSAg }\end{array}$ \\
\hline HCV antibody & $\begin{array}{l}\text { To all IAC; repeat } \\
\text { after } 3 \text { months in } \\
\text { IAC at risk }\end{array}$ & $\begin{array}{l}\text { To all IAC; repeat } \\
\text { after } 6 \text { months if } \\
\text { clinical suspicion }\end{array}$ & $\begin{array}{l}\text { To all IAC; } \\
\text { consider window } \\
\text { period }\end{array}$ & $\begin{array}{l}\text { To all IAC; repeat } \\
\text { after } 6 \text { months }\end{array}$ & To all IAC & $\begin{array}{l}\text { To all IAC; repeat } \\
\text { after } 6 \text { months }\end{array}$ \\
\hline $\begin{array}{l}\text { HAV serologic testing } \\
(\operatorname{lgG} ; \operatorname{lgM})\end{array}$ & $\begin{array}{l}\text { Not } \\
\text { recommended }\end{array}$ & $\begin{array}{l}\text { To IAC coming } \\
\text { from Latin } \\
\text { America }\end{array}$ & To all IAC & To all IAC & To all IAC & To all IAC \\
\hline $\begin{array}{l}\text { HIV 1-2 serologic } \\
\text { testing }\end{array}$ & $\begin{array}{l}\text { To all IAC; repeat } \\
\text { after } 3 \text { months in } \\
\text { IAC at risk }\end{array}$ & $\begin{array}{l}\text { To all IAC; repeat } \\
\text { after 3-6 months } \\
\text { in IAC at risk }\end{array}$ & $\begin{array}{l}\text { To all IAC; } \\
\text { consider window } \\
\text { period }\end{array}$ & $\begin{array}{l}\text { To all IAC; repeat } \\
\text { after } 6 \text { months }\end{array}$ & To all IAC & To all IAC \\
\hline Non-treponemal tests & To all IAC & To all IAC & Not specified & To all IAC & To all IAC & To all IAC \\
\hline Treponemal tests & $\begin{array}{l}\text { Not } \\
\text { recommended }\end{array}$ & $\begin{array}{l}\text { If } \\
\text { non-treponemal } \\
\text { test is positive }\end{array}$ & Not specified & Not recommended & To all IAC & To all IAC \\
\hline TST & $\begin{array}{l}\text { To all IAC; repeat } \\
\text { after } 6 \text { months if } \\
\text { negative }\end{array}$ & To all IAC & To all IAC & To all IAC; or IGRA & $\begin{array}{l}\text { To all IAC + chest } \\
\text { x-ray }\end{array}$ & $\begin{array}{l}\text { To all IAC; } \\
\text { preferred }<5 \\
\text { years of age; } \\
\text { repeat after } 6 \\
\text { months from } \\
\text { arrival; or IGRA }\end{array}$ \\
\hline IGRA & $\begin{array}{l}\text { Not } \\
\text { recommended }\end{array}$ & $\begin{array}{l}\text { Not } \\
\text { recommended }\end{array}$ & If TST is positive & $\begin{array}{l}\text { To IAC older than } \\
2 \text { years; or TST }\end{array}$ & Not recommended & $\begin{array}{l}\text { To all IAC; } \\
\text { preferred } \geq 5 \\
\text { years; repeat } \\
\text { after } 6 \text { months } \\
\text { from arrival; or } \\
\text { TST }\end{array}$ \\
\hline Ova and parasite exam & $\begin{array}{l}\text { Only to IAC at } \\
\text { risk }\end{array}$ & To all IAC & To all IAC & To all IAC & To all IAC & To all IAC \\
\hline Giardia lamblia antigen & $\begin{array}{l}\text { Not } \\
\text { recommended }\end{array}$ & $\begin{array}{l}\text { Not } \\
\text { recommended }\end{array}$ & $\begin{array}{l}\text { Not } \\
\text { recommended }\end{array}$ & Not recommended & Not recommended & $\begin{array}{l}\text { To all IAC; } 1 \\
\text { sample }\end{array}$ \\
\hline $\begin{array}{l}\text { Cryptosporidium spp. } \\
\text { antigen }\end{array}$ & $\begin{array}{l}\text { Not } \\
\text { recommended }\end{array}$ & $\begin{array}{l}\text { Not } \\
\text { recommended in }\end{array}$ & $\begin{array}{l}\text { Not } \\
\text { recommended }\end{array}$ & Not recommended & Not recommended & $\begin{array}{l}\text { To all IAC; } 1 \\
\text { sample }\end{array}$ \\
\hline $\begin{array}{l}\text { Toxocara canis/cati } \\
\text { specific antibodies }\end{array}$ & $\begin{array}{l}\text { Not } \\
\text { recommended }\end{array}$ & $\begin{array}{l}\text { Not } \\
\text { recommended }\end{array}$ & $\begin{array}{l}\text { Hypereosinophilia } \\
\text { with negative } \\
\text { parasitic stool } \\
\text { examination }\end{array}$ & Not recommended & Not recommended & $\begin{array}{l}\text { Hypereosinophilia } \\
\text { with negative } \\
\text { parasitic stool } \\
\text { examination }\end{array}$ \\
\hline $\begin{array}{l}\text { Strongyloides spp. } \\
\text { specific antibodies }\end{array}$ & $\begin{array}{l}\text { Not } \\
\text { recommended }\end{array}$ & $\begin{array}{l}\text { Not } \\
\text { recommended }\end{array}$ & $\begin{array}{l}\text { Hypereosinophilia } \\
\text { with negative } \\
\text { parasitic stool } \\
\text { examination }\end{array}$ & $\begin{array}{l}\text { To IAC from } \\
\text { endemic areas }\end{array}$ & Not recommended & $\begin{array}{l}\text { Hypereosinophilia } \\
\text { with negative } \\
\text { parasitic stool } \\
\text { examination }\end{array}$ \\
\hline $\begin{array}{l}\text { Schistosoma spp. } \\
\text { specific antibodies }\end{array}$ & $\begin{array}{l}\text { Not } \\
\text { recommended }\end{array}$ & $\begin{array}{l}\text { Not } \\
\text { recommended }\end{array}$ & $\begin{array}{l}\text { Hypereosinophilia } \\
\text { with negative } \\
\text { parasitic stool } \\
\text { examination }\end{array}$ & $\begin{array}{l}\text { To IAC from } \\
\text { endemic areas }\end{array}$ & Hypereosinophilia & $\begin{array}{l}\text { To IAC from } \\
\text { endemic areas }\end{array}$ \\
\hline $\begin{array}{l}\text { Trypanosoma cruzi } \\
\text { antibodies }\end{array}$ & $\begin{array}{l}\text { Not } \\
\text { recommended }\end{array}$ & $\begin{array}{l}\text { IAC from Latin } \\
\text { America }\end{array}$ & $\begin{array}{l}\text { Not } \\
\text { recommended }\end{array}$ & Not recommended & Not recommended & $\begin{array}{l}\text { IAC from } \\
\text { Mexico, Central } \\
\text { America, and } \\
\text { South America }\end{array}$ \\
\hline Stool culture & $\begin{array}{l}\text { Clinical } \\
\text { suspicion }\end{array}$ & $\begin{array}{l}\text { Clinical } \\
\text { suspicion }\end{array}$ & $\begin{array}{l}\text { Clinical } \\
\text { suspicion }\end{array}$ & Clinical suspicion & Clinical suspicion & $\begin{array}{l}\text { Clinical } \\
\text { suspicion }\end{array}$ \\
\hline Tests for Malaria & $\begin{array}{l}\text { To all IAC from } \\
\text { an endemic } \\
\text { area; repeated if } \\
\text { clinical suspicion }\end{array}$ & $\begin{array}{l}\text { Clinical } \\
\text { suspicion in IAC } \\
\text { from India, Asia, } \\
\text { Sub-Saharan } \\
\text { Africa, Latin } \\
\text { America }\end{array}$ & $\begin{array}{l}\text { Clinical } \\
\text { suspicion }\end{array}$ & Clinical suspicion & Clinical suspicion & $\begin{array}{l}\text { Clinical } \\
\text { suspicion in IAC } \\
\text { from an endemic } \\
\text { area }\end{array}$ \\
\hline
\end{tabular}

HBV, Hepatitis B virus; HCV, Hepatitis C virus; HAV, Hepatitis A virus; HIV, Human Immunodeficiency Virus; TST, tuberculin skin test; IGRA, Interferon Gamma Release Assay. 
To the best of our knowledge, this is the first study comparing existing protocols for the screening of infectious diseases in IAC. A limitation of this study is that some protocols may have been missed by our research and that the comparison among the protocols may be affected by the different levels of methodological quality and different years of publication. Moreover, these protocols might not reflect the common practice in these countries, since heterogeneity has been reported among different centers in the same country, and more recent evidence might guide current management (2).

Most protocols were provided on a national level, whereas in France, a systematic national approach does not exist, and we reported the regional approach of a Medical Guidance for Adopted Children Consultation (13).

All the protocols report sets of screening tests that allow early detection of serious infectious conditions and those most commonly reported among IAC (9-14).

All the retrieved protocols recommend screening for human immunodeficiency virus (HIV), Hepatitis B virus (HBV), Hepatitis $\mathrm{C}$ virus (HCV), Tuberculosis, syphilis, and intestinal parasites (9-14).

The main discrepancies among the protocols regard the recommendations for screening of the Hepatitis A virus (HAV), malaria, and other parasitic infections.

HAV serology testing is not required by the UK protocol and is recommended only in children coming from an endemic area by Spanish protocol, whereas it is routinely recommended for all IAC by the other protocols. HAV infection among IAC is frequent, and cases of transmission to adoptive families have been reported (15-19). In an American study including 656 IAC, $4.6 \%$ were positive for HAV infection, even if they did not show any symptoms (15). They came mostly from Ethiopia and Guatemala (15). This screening may be important so that preventive measures can be started promptly, since many cases of HAV have been reported among the components of adoptive families (15-19).

Among the retrieved protocols, only the UK protocol recommends screening for malaria in IAC coming from endemic areas (9). The introduction of a screening test for malaria in IAC coming from malaria-endemic countries has also recently been supported in Italy after several cases were reported of asymptomatic children with malaria coming from the African continent (20). Either Polymerase Chain Reaction (PCR) or thin and thick strip microscopy have been reported as valid screening tests $(20,21)$.

Intestinal parasitic infections are very common in IAC: up to $27 \%$ of children arriving in the US may have one or more parasitic infections $(1,18,22)$. In Italy, the prevalence of intestinal parasitic infections among IAC is $23 \%$ (3). The most frequently observed parasitic infections are Giardia lamblia and Toxocara canis $(1,18,22)$. All the protocols routinely recommend an ova and parasite exam on three stool samples, except for the British one, which indicates this exam only whether a clinical suspicion is posed.

Only some of the protocols recommend serology testing for Strongyloides spp. and Schistosoma spp. where there is clinical suspicion or when the child comes from an endemic area. The recently published European Centre for Disease Prevention and Control (ECDC) protocol for screening of infectious diseases in migrants recommends screening of Strongyloides spp. and Schistosoma spp. among all migrants coming from endemic areas (23).

Other relevant differences among the protocols regard the choice of the elective test for the screening of latent tuberculosis infection (LTBI) and syphilis and the specific antibodies and the timing of serology of HBV.

Since many IAC have been vaccinated with BCG and have undergone numerous TSTs, the TST results are difficult to interpret, and discrepancies between TST and IGRA have frequently been reported $(24,25)$. Higher rates of positive TST were observed in children recently vaccinated with BCG, while TST positivity rates were less frequent in those who had been vaccinated less recently (15 years before) (26).

The ECDC protocol for screening and vaccination for infectious diseases in newly arrived migrants (either adults or children) to European Union countries indicates either the use of TST or IGRA but does not specify the preferred test per age (23).

It has been reported that IGRA showed higher specificity overall than TST, but it may have lower sensitivity in children under 5 years of age $(1,3,24)$. For this reason, the US protocol and the recent Italian guidelines for the diagnosis of tuberculosis in migrants prefer the use of TST for children $<5$ years of age (27). On the other hand, some experts suggest the use of only IGRA also in children as young as 2 years if a good follow-up can be assured (28). Moreover, IGRA has been reported to be preferred when IAC are unlikely to return for TST reading $(7,8)$.

In a review of cost-effectiveness studies, LTBI screening in migrants was reported to be cost-effective according to seven studies, especially in young subjects from high-incidence countries. IGRA was the most cost-effective test for LTBI screening in migrants in four studies (29).

The prevalence of HBV infection among adopted children has been estimated to be around $2-5 \%(18,30)$. It is essential to detect the infection in order to manage the infected child and to avoid contagion of adopting families.

Discrepancies have been found regarding the antibodies required and the timing.

During the window period, the only marker of acute infection is anti-HBc, which is highly specific for establishing the diagnosis of acute infection (31). For this reason, Spain recommends repeating the serology after 3-6 months if $\mathrm{HBcAb}$ has not been tested at arrival (10).

The recent ECDC protocol for screening of infectious diseases in migrants recommends dosing $\mathrm{HBsAg}$, anti-HBc, and HBs$\mathrm{Ab}$ to migrants from intermediate-/high-prevalence countries ( $\geq 2-\geq 5 \%$ HBsAg) (23).

The prevalence of syphilis amounted to $3 \%$ in two studies conducted on $\operatorname{IAC}(1,18)$. The use of only one type of test may be insufficient for diagnosis because false-positive non-treponemal test results occur with various medical conditions and because treponemal test results remain positive long after syphilis has been treated adequately and can be falsely positive with other spirochetal diseases (32). 
Many factors may justify these discrepancies. These protocols were published in different periods, with the British protocol being produced in 2004 and the Spanish in 2008 (9, 10). Therefore, new evidence may have been included in the protocols more recently produced by Italy, the US, France, and Canada (11-14).

Another relevant factor is that every receiving country deals with heterogeneous groups of IAC in terms of country of origin and age (1). This fact may affect the prevalence of infectious diseases in each group. For example, the serologic testing for Strongyloides spp. and Schistosoma spp. in IAC coming from endemic areas is routinely recommended by the Spanish protocol but not in the other countries. This may result from the high number of and greater experience with children coming from African countries (33).

Moreover, these features constantly change according to new adoptive policies in the countries of origin and the incidence of infectious diseases in that specific period (1). For these reasons, the frequency of infectious diseases among IAC is not easily measurable $(1,33)$.

Furthermore, the discrepancies between the screening protocols reflect the lack of international consensus regarding some areas, such as the appropriate test for LTBI $(24,25)$. Furthermore, different studies conducted in the same country report different screening protocols, showing that approaches are not only internationally heterogeneous (2).

Cost-effectiveness studies have been performed that documented the cost-effectiveness of some screening tests in migrants (either children or adults), but further studies may

\section{REFERENCES}

1. Obringer E, Walsh L. Infectious disease and immunizations in international adoption. Pediatr Ann. (2017) 46:e56-60. doi: 10.3928/19382359-20170117-01

2. Sollai S, Ghetti F, Bianchi L, de Martino M, Galli L, Chiappini E. Infectious diseases prevalence, vaccination coverage, and diagnostic challenges in a population of internationally adopted children referred to a Tertiary Care Children's Hospital from 2009 to 2015. Medicine (Baltimore). (2017) 96:e6300. doi: 10.1097/MD.0000000000006300

3. Ampofo K. Infection diseases issues in adoption of young children. Curr Opin Pediatr. (2013) 25:78-87. doi: 10.1097/MOP.0b013e32835c1357

4. Staat DD, Klepser ME. International adoption: issues in infectious diseases. Pharmacotherapy. (2006) 26:1207-20. doi: 10.1592/phco.26.9.1207

5. Hostetter MK, Iverson S, Dole K, Johnson D. Unsuspected infectious diseases and other medical diagnoses in the evaluation of internationally adopted children. Pediatrics. (1989) 83:559-64.

6. Whitaker-Worth DL, Bayart CB, Benedetti JA. Dermatologic conditions in internationally adopted children. Int J Womens Dermatol. (2015) 1:316. doi: 10.1016/j.ijwd.2014.12.003

7. Sciauvaud J, Rigal E, Pascal J, Nourrisson C, Poirier P, Poirier V., et al. Transmission of infectious diseases from internationally adopted children to their adoptive families. Clin Microbiol Infect. (2014) 20:74651. doi: 10.1111/1469-0691.12454

8. Selman, P. Statistics Based on Data Provided by 24 Receiving States. The Hague Commission Website (2018).

9. Baaf Adoption and Forestering. Health Screening of Children Adopted From Abroad. (2019). Available online at: https://www.actionforchildren.org.uk/ media/5772/baaf_health_screeening.pdf (accessed May 16, 2019).

10. Coordinadora de asociaciones de adopcion y acogimiento (CORA). Guia consensuada de Salud en Adopción Internacional CORA. (2008). Available be needed focusing specifically on adopted children $(22,34)$. Recently, the ECDC has produced guidance on screening and vaccination for infectious diseases in newly arrived migrants within the European Union (23). This document is a useful instrument but has the limitation of dealing with both adults and children and does not focus specifically on IAC, who are a high-risk, unusual population.

A systematic approach categorized per country of origin and age may be useful, to be integrated with the information coming from the history and examination of the child.

Since the screening protocols used in different countries are not homogenous, the introduction of an optimized internationally shared protocol focusing on IAC would be highly desirable to fill the potential gaps in local protocols. Moreover, an international consensus on the proper screening of LTBI in this group of children would be highly desirable.

\section{AUTHOR CONTRIBUTIONS}

EC, BB, SB, SS, TM, MM, and LG conceived the study, reviewed the literature, and drafted the manuscript. All the authors read and approved the final manuscript.

\section{FUNDING}

This work received no fundings. The payment of fees for open access publication will be supported by the Dipartimento di Medicina Sperimentale e Clinica of the University of Florence. online at: https://www.coraenlared.org/2008/01/01/guia-consensuada-desalud-en-adopci'on-internacional-cora-2008 (accessed May 17, 2019).

11. Gruppo di lavoro nazionale per l'accoglienza del bambino migrante della Società Italiana di Pediatria GLNBI. Indicazioni del glnbi-sip per l'accoglienza sanitaria al minore migrante. (2013). Avalaible online at: http://www.glnbi. org/documenti/0aba8ee7817afd2e8917c913ebe30189.pdf (accessed May 17, 2019).

12. Caring for Kids New to Canada. International Adoption: Health Evaluation of the International Adoptee. Canadian pediatric society. Available online at: https://www.kidsnewtocanada.ca/screening/health-evaluationinternational-adoptee

13. Hénaff F, Hazart I, Picherot G, Baqué F, Gras-Le Guen C, Launay E. Frequency and characteristics of infectious diseases in internationally adopted children: a retrospective study in Nantes from 2010 to 2012. J Travel Med. (2015) 22:179-85. doi: 10.1111/jtm.12196

14. Center for Disease Control and Prevention. International Adoption. Chapter 7 International Travel with Infants \& Children. Available online at: https:// wwwnc.cdc.gov/travel/yellowbook/2018/international-travel-with-infantschildren/international-adoption (accessed May 17, 2019).

15. Sweet K, Sutherland W, Ehresmann K, Lynfield R. Hepatitis A infection in recent international adoptees and their contacts in Minnesota, 2007-2009. Pediatrics. (2011) 128:e333-8. doi: 10.1542/peds.201 $0-1840$

16. Abdulla RY, Rice MA, Donauer S, Hicks KR, Poore D, Staat MA. Hepatitis A in internationally adopted children: screening for acute and previous infections. Pediatrics. (2010) 126:e1039-44. doi: 10.1542/peds.20 10-0120

17. Fischer GE, Teshale EH, Miller C, Schumann C, Winter K, Elson F, et al. Hepatitis A among international adoptees and their contacts. Clin Infect Dis. (2008) 47:812-4. doi: 10.1086/591199 
18. Saiman L, Aronson J, Zhou J, Gomez-Duarte C, Gabriel PS, Alonso M., et al. Prevalence of infectious diseases among internationally adopted children. Pediatrics. (2001) 108:608-12. doi: 10.1542/peds.108.3.608

19. Raabe VN, Sautter C, Chesney M, Eckerle JK, Howard CR, John CC. Hepatitis A screening for internationally adopted children from Hepatitis A endemic countries. Clin Pediatr. (2014) 53:31-7. doi: 10.1177/0009922813505903

20. Chiappini E, Sollai S, de Martino M, Galli L. Malaria in children adopted from the Democratic Republic of the Congo. Emerg Infect Dis. (2017) 23:7212. doi: 10.3201/eid2304.161777

21. American Academy of Pediatrics. Malaria. In: Kimberlin DW, Brady MT, Jackson MA, Long SS, editors. Red Book: 2018 Report of the Committee on Infectious Diseases. 31st ed. Itasca, IL: American Academy of Pediatrics (2018). p. 527-37.

22. Staat MA, Rice M, Donauer S, Mukkada S, Holloway M, Cassedy A., et al. Intestinal parasite screening in internationally adopted children: importance of multiple stool specimens. Pediatrics. (2011) 128:61322. doi: 10.1542/peds.2010-3032

23. Public Health Guidance on Screening and Vaccination for Infectious Diseases in Newly Arrived Migrants Within the EU/EEA. Available online at: https:// ecdc.europa.eu/en/publications-data/public-health-guidance-screeningand-vaccination-infectious-diseases-newly (accessed May 17, 2019).

24. Spicer KB, Powell DA. Immunizations for internationally adopted children. Pediatr Ann. (2010) 39:517-34. doi: 10.3928/00904481-20100726-10

25. Lowenthal P, Barry PM, Flood J. High discordance between pre-US and postUS entry tuberculosis test results among immigrant children: is it time to adopt interferon gamma release assay for preentry tuberculosis screening? Pediatr Infect Dis J. (2016) 35:231-6. doi: 10.1097/INF.0000000000000986

26. Wang L, Turner MO, Elwood RK, Schulzer M, FitzGerald JM. A meta-analysis of the effect of Bacille Calmette Guérin vaccination on tuberculin skin test measurements. Thorax. (2002) 57:804-9. doi: 10.1136/thorax.57.9.804

27. Italian Health Institute. Guidelines for Tuberculosis Screening Among Recent Immigrants in Italy. Available online at: www.simetweb.eu/document/3937 (accessed April 27, 2018).

28. Priya Dhar C, Elena Gonzalez B, Dragga T, Bothe D, Mandalakas AM. Testing international adoptees for tuberculosis. Pediatr Infect Dis J. (2015) 34:1138-9. doi: 10.1097/INF.0000000000000829
29. Zammarchi L, Casadei G, Strohmeyer M, Bartalesi F, Liendo C, Matteelli A., et al. A scoping review of cost-effectiveness of screening and treatment for latent tubercolosis infection in migrants from high-incidence countries. BMC Health Serv Res. (2015) 15:412. doi: 10.1186/s12913-0151045-3

30. Stadler LP, Mezoff AG, Staat MA. Hepatitis B virus screening for internationally adopted children. Pediatrics. (2008) 122:12238. doi: 10.1542/peds.2007-2559

31. American Academy of Pediatrics. Hepatitis B. In: Kimberlin DW, Brady MT, Jackson MA, Long SS, editors. Red Book: 2018 Report of the Committee on Infectious Diseases. 31st ed. Itasca, IL: American Academy of Pediatrics (2018). p. 401-28.

32. American Academy of Pediatrics. Syphilis. In: Kimberlin DW, Brady MT, Jackson MA, Long SS, editors. Red Book: 2018 Report of the Committee on Infectious Diseases. 31st ed. Itasca, IL: American Academy of Pediatrics (2018). p. 773-88.

33. Martínez Ortiz A, Domínguez Pinilla N, Wudineh M, González-Granado LI. International adoption from Ethiopia in a 5-year period. An Pediatr (Barc). (2015) 82:302-7. doi: 10.1016/j.anpede.2015.04.008

34. Myran DT, Morton R, Biggs BA, Veldhuijzen I, Castelli F, Tran A., et al. The effectiveness and cost-effectiveness of screening for and vaccination against Hepatitis B virus among migrants in the EU/EEA: a systematic review. Int J Environ Res Public Health. (2018) 15:E1898. doi: 10.3390/ijerph15 091898

Conflict of Interest: The authors declare that the research was conducted in the absence of any commercial or financial relationships that could be construed as a potential conflict of interest.

Copyright (C) 2019 Chiappini, Bortone, Borgi, Sollai, Matucci, Galli and de Martino. This is an open-access article distributed under the terms of the Creative Commons Attribution License (CC BY). The use, distribution or reproduction in other forums is permitted, provided the original author(s) and the copyright owner(s) are credited and that the original publication in this journal is cited, in accordance with accepted academic practice. No use, distribution or reproduction is permitted which does not comply with these terms. 